\title{
Scolytinae species damaging Carya illinoinensis trees in southern Brazil ${ }^{1}$
}

\author{
Tales Poletto ${ }^{2 *}$ (D) Ervandil Corrêa Costa ${ }^{2}$, Dayanna do Nascimento Machado², Jéssica Maus da Silva ${ }^{2}$, \\ Clérison Régis Perini ${ }^{2}$, Marlove Fátima Brião Muniz ${ }^{2}$
}

$10.1590 / 0034-737 X 202067020008$

\begin{abstract}
This study aims to report two species of Scolytinae that have been damaging Carya illinoinensis trees in southern Brazil. In two Brazilian municipalities, Guarapuava in Paraná State and Pantano Grande in the Rio Grande do Sul State, insects of the Scolytinae family were found damaging pecan trees. Infested tree samples were kept in the laboratory in glass tubes sealed with a voile tissue until the emergence of adults. After the adults' emergence, the specimens were identified by their morphological characteristics and sent to a taxonomist specialized in Scolytinae family for identification. The species Xyleborus retusus was identified causing damages to pecan trees from Guarapuava while the species Xyleborus ferrugineus was identified in pecan trees from Pantano Grande. Trees injured by these insects displayed similar symptoms in both study areas. In Guarapuava and Pantano Grande, 13 and 10 trees, respectively, died due to stem lesions caused by Xyleborus spp. Thus, this study reports for Brazilian pecan growers the occurrence of Scolytinae species $X$. retusus and $X$. ferrugineus damaging $C$. illinoinensis plants in southern Brazil. It also emphasizes the importance of constant crop monitoring to minimize the risk of pest damage.
\end{abstract}

Keywords: Forest Entomology; pest management; pecan.

\section{INTRODUCTION}

The species Carya illinoinensis (Wangenh.) K. Koch is distributed naturally in a continuous area from Mexico to the state of Illinois in the United States (McWilliams, 2013). The cultivation of this species has been growing rapidly in Brazil, with new orchards established mainly in the states of Rio Grande do Sul, Santa Catarina, and Paraná. Besides composing large orchards, pecan crops are also present in numerous small farms due to their use in agroforestry systems, shading of aviaries, wood production, and ornamentation. In 2016, the Brazilian production reached 5.453 tons of nuts (dry fruit), from a total of 3.503 planted hectares (IBGE, 2016). As a consequence of the increase in the area of pecan cultivation in southern Brazil, there has been a significant increase in the incidence of insects, which cause damage to the crop (Boscardin \& Costa, 2018).
The pest species Monellia caryella (Fitch, 1855) (blackmargined aphid), Phylloxera devastatrix Pergande, 1904 and Phylloxera notabilis Pergande, 1903 (phylloxera), are highlighted as being of major importance due to their occurrence in Brazil (Rio Grande do Sul) and the United States, causing damage to leaves (Boscardin \& Costa, 2018). It should be noted that the phytophagous insect species Leptoglossus stigma (Herbst, 1784), Leptoglossus zonatus (Dallas, 1852) (Hemiptera: Coreidae) and Loxa deducta (Walker, 1867) damage the fruit, implicating in low orchard productivity (Boscardin et al., 2016). Besides these species, coleopteran species (Coleoptera: Curculionidae, Scolytinae) are noteworthy, since these beetles, known as bark beetles and ambrosia beetle, are considered the most harmful in native and planted forests (Raffa et al., 2015).

The bark beetles build galleries initially on the phloem, or sometimes on the sapwood, from where they feed and

\footnotetext{
Submitted on September 11 $1^{\text {th }}, 2019$ and accepted on February 10 $0^{\text {th }}, 2020$.

${ }^{1}$ Information extracted from Doctoral Thesis in progress.

${ }^{2}$ Universidade Federal de Santa Maria, Departamento de Defesa Fitossanitária, Santa Maria, Rio Grande do Sul, Brazil. tecnicotales@hotmail.com; ervandilc@gmail.com; dayanasmac@gmail.com; smausjessica@gmail.com; periniagro@gmail.com; marlovemuniz@yahoo.com.br

*Corresponding author: tecnicotales@hotmail.com
} 
are characterized by high host specificity (Wood, 1982; Rassati et al., 2016). Ambrosia beetles establish breeding galleries in wood and feed of symbiotic fungi rather than directly on plant tissues. In addition, they are less specific regarding their hosts (Wood, 1982; Raffa et al., 2015) and are considered as the dominant group in Brazil, especially the species from the Xyleborini tribe (Flechtmann et al., 1995). In the Rio Grande do Sul State, two species of the genus Corthylus and one species of the genus Xyleborinus have been reported to harm $C$. illinoinensis trees (Boscardin, 2016). The identification and monitoring of pecan pests are fundamental to the adoption of Integrated Pest Management strategies. Thus, this study aims to report the occurrence and damages caused by two species of Scolytinae in pecan trees in southern Brazil.

\section{MATERIAL AND METHODS}

From December 2016 to January 2017, injuries caused by insects on four-year-old pecan trees were observed in an area of two hectares in the town of Guarapuava (25 23'27 ' S and 51 27'4"' W), state of Paraná, Brazil. The climate of this region is classified as subtropical humid oceanic, without a dry season and with temperate summer (Cfb) (Alvares et al., 2017). The symptoms were observed on the outer parts of the trees, such as the presence of sawdust, circular entrance and exit holes, senescent leaves, and complete dryness of the canopy.

In the town of Pantano Grande (30'11'24' $\mathrm{S}$ and $52^{\circ} 22^{\prime} 24^{\prime \prime}$ W), state of Rio Grande do Sul, symptoms similar to those observed in Guarapuava were observed in a 55 ha pecan farm with five-year-old trees during November, December 2017 and January 2018. In this region, the climate is classified as subtropical humid oceanic, without a dry season and with hot summer (Cfa) (Alvares et al., 2017). In an area of four hectares, trees displayed 'wilted' canopies, several of them having yellowish leaves. The presence of perforations and insect larvae were observed after removing a piece of bark from the stem.

Fragments of the stems with insect damage of four dead trees from both locations (from Guarapuava in December 2016 and from Pantano Grande in November 2017) were collected and sent to the Forest Entomology Laboratory of the Universidade Federal de Santa Maria, RS. The material was stored in glass containers $(60 \mathrm{~cm}$ high $\mathrm{x} 30 \mathrm{~cm}$ in diameter), separated by sampling sites and covered with a mesh until the emergence of adult insects, which initiated in January 2017 to samples from Guarapuava and in December 2017 to samples from Pantano Grande.

Afterward, the Scolytinae specimens were collected and stored in $1.5 \mathrm{~mL}$ tubes containing $70 \%$ alcohol. The specimens emerged from stems (113 females and 8 males from Guarapuava; and 138 females and 11 males from Pantano Grande) were sent to a specialist for identification. Then, the specimens were identified by a taxonomist based on the morphological characteristics of Scolytinae species. In addition, fragments of stems were sectioned in the longitudinal and transverse directions to allow visualizing the presence of galleries and insects inside the wood.

\section{RESULTS AND DISCUSSION}

In Guarapuava, 13 dead trees were recorded due to injuries caused by insects identified as Xyleborus retusus (Eichhoff, 1868) (Figure 1). Some trees were removed from the plantation and sectioned (Figure 2A), revealing the presence of adults in the external and internal parts of the wood (Figure 2B). From the longitudinal and transversal cuts in the trunk and branches, it was possible to visualize internal galleries and black staining in the cambial layers (mainly in galleries) (Figure 2C).

A total of 30 injured trees were found in Pantano Grande, from which 10 died due to the occurrence of one species of Scolytinae identified as Xyleborus ferrugineus Fabricius, 1801(Figure 3). Some injured trees presented perforations in the trunk (Figure 4A) and were cut into smaller parts to facilitate the visualization of the damage caused by larvae and adults of $X$. ferrugineus (Figure 4B). From the longitudinal section of some trees, internal symptoms similar to those found in Guarapuava were observed, such as the presence of dark stains in the wood (Figure 4C).

Pecan cultivation can be economically important in family farming properties not only due to low implantation costs but also because it allows the implantation of an integrated system with pastures. In addition, both the wood (considered noble and useful in the formation of legal reserve in properties) and the walnut are marketable

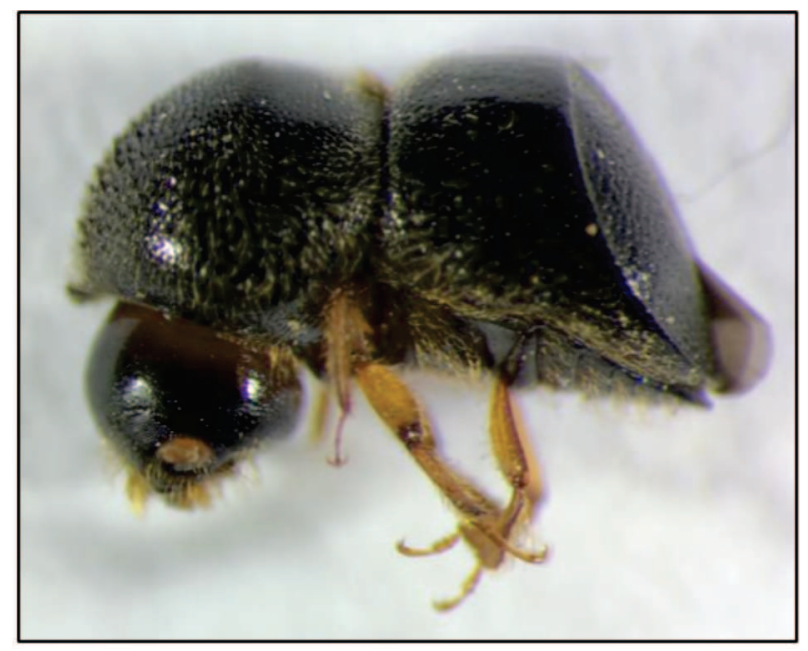

Figure 1: Adult individual of Xyleborus retusus. 


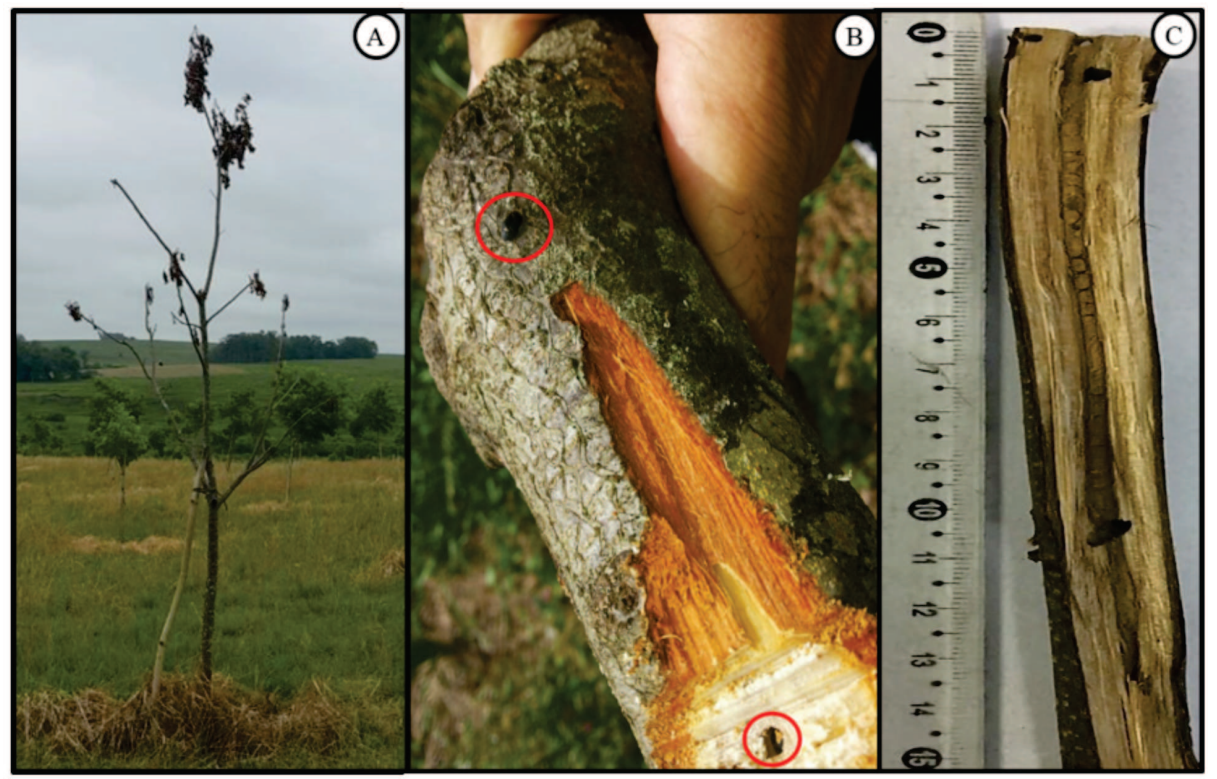

Figure 2: Pecan's plantation in Guarapuava, PR, Brazil. Young pecan tree dead as a result of Xyleborus retusus infestation (A); adult individual and its bore in the wood (B); galleries caused by Xyleborus retusus (C).

products (Divinut, 2016). In this sense, the occurrence of pests such as Scolytinae (that may lead to the death of plants in an orchard) may harm the production of fruits and noble wood even before the crops become profitable.

The species found in Guarapuava and Pantano Grande belong to the Xyloborini tribe. This tribe is considered as one of the most important from Scolytinae due to the species causing significant damages to different types of monocultures, including the black wattler (Machado et al. 2014). Species from the Scolytinae and Platypodinae (Coleoptera: Curculionidae) subfamilies initially feed on stressed or damaged trees. However, when reaching high population levels, they may injure healthy plants (CarranoMoreira, 2014).

The damage caused by Xyleborus spp. is characterized by the opening of galleries by adult insects through the bark directly into the sapwood, leaving grained sawdust on the outside of the entrance opening (Solomon \& Payne, 1986; Boscardin \& Costa, 2018). When galleries are active, they have a light coloration and no sawdust, whereas the unoccupied galleries have a dark color due to the symbiotic fungi (Solomon \& Payne, 1986). These fungi reduce plant defenses and deteriorate wood, making it more nutritious for larvae and adults (Gullan \& Cranston, 2014). In addition, the insect damage weakens the plant, leaving it vulnerable to disease, which may render it unfeasible for commercial purposes and even kill the host tree (Solomon \& Payne, 1986).

Climatic factors comprising temperature and humidity are extremely important for Xyleborus species development and its symbiotic fungi because they are dependent on ideal conditions for the fungal development in the galleries (Wood, 1982). Climate change and anthropic action are under intensification in recent years and are increasingly influencing the biology and behavior of insects and also expanding their hosts. Homogeneous cultivations are an easier alternative to insect adaptation, feeding and increasing its population density.

Boscardin (2016) carried out a study in the Rio Grande do Sul State on the symptomatology of the damage caused by Scolytinae (Corthylus sp.1, Corthylus sp.2, and Xyleborinus sp.) in pecan trees. This author considered water stress as a central aspect of conditioning the trees for the emission of phenolic compounds that attract these insects (Boscardin, 2016). The symptoms reported by the author were the presence of holes and sawdust in the trunk, senescent leaves and death of trees after 2-4 weeks as external symptoms, and wood stains and insect entry/ emergence holes as internal symptoms. These symptoms are similar to those caused by $X$. retusus and $X$. ferrugineus.

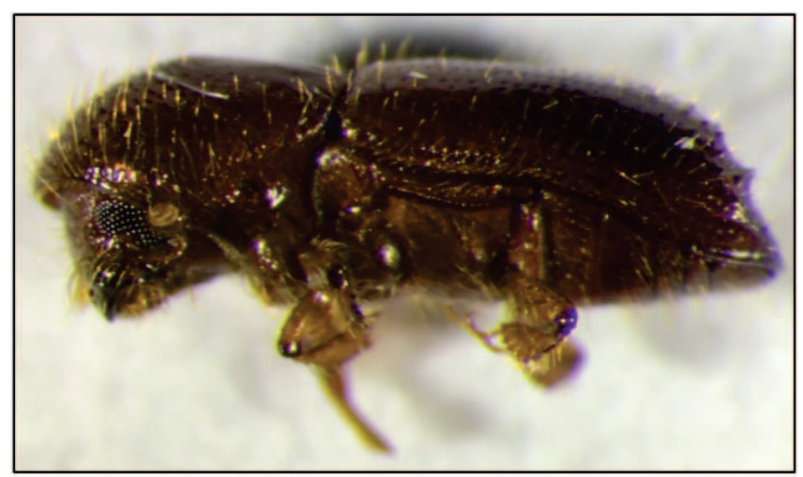

Figure 3: Adult individual of Xyleborus ferrugineus

Rev. Ceres, Viçosa, v. 67, n.2, p. 147-151, mar/apr, 2020 


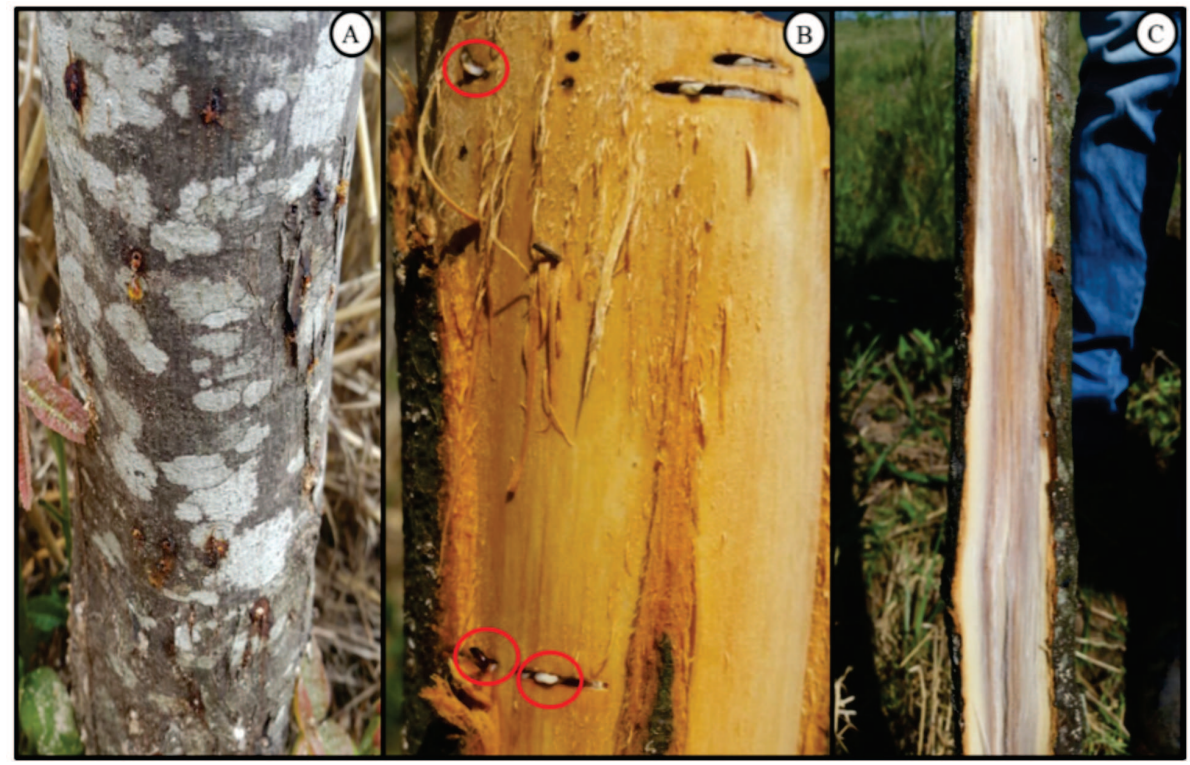

Figure 4: Pecan's plantation in Pantano Grande. Injured tree presenting perforations in the trunk by Xyleborus ferrugineus (A); larvae and adult specimen of Xyleborus ferrugineus inside the trunk (B); and wood staining by fungus (C).

The species $X$. ferrugineus along with $X$. affinis are considered the most destructive species in eucalyptus plantations in Brazil (Flechtmann, 2000). X. ferrugineus is considered as the primary vector of the pathogenic fungus Ceratocystis fimbriata (Ciesla, 2011; Wollmann et al., 2017) and may leave injuries in woody plants with more than 10 cm in diameter (Wood, 1982; Wollmann et al., 2017). In a survey of scolytidae in plantations of Eucalyptus spp. in Cuiabá, state of Mato Grosso, Brazil, the species Xyleborus spinosulus (Schedl, 1934), X. retusus and X. ferrugineus were quantitatively the most important (Dorval et al., 2004). Therefore, $X$. retusus and X. ferrugineus are potential pests in pecan plantations.

The wide occupation of monocultures intensifies the emergence of entomological problems, which must be constantly monitored to recognize the pests and their damages, which can reduce the growth and yield of pecan trees. Although there is no Integrated Pest Management (IPM) program for pecan trees, the basic IPM strategies, as identification, monitoring, and evaluation of yield loss per unit of injury, should be used and investigated in orchards to reduce and to avoid economic losses. Scolytinae insects in pecan should be monitored with ethanolic traps distributed in the orchard for the capture and later identification of the species. Studies on the biology and ecology of these insects and on their natural enemies are important.

\section{CONCLUSIONS}

Damages identified on the stem of pecan trees in Guarapuava (Paraná State) and Pantano Grande (Rio Grande do Sul State) were caused by two species of Xyleborus
(Scolytinae). The potential risk of insect pests, as well as the quantification of their damages in $C$. illinoinensis crops, are extremely important to the proper management of the species. The constant monitoring of pecan cultivation is a practical and rapid action to be taken, assisting in the early detection of entomological problems. It is important to highlight that this is the first report of occurrence of the scolytinae species $X$. retusus and $X$. ferrugineus, causing damage to stem and mortality of $C$. illinoinensis plants in Brazil.

\section{ACKNOWLEDGMENTS}

The authors would like to thank Professor Dr. Eli Nunes Marques, from Federal University of Paraná, for identifying the Scolitinae species and Coordenação de Aperfeiçoamento de Pessoal de Nível Superior - CAPES - by the scholarship granted to the first author.

Authors inform that there is no conflict of interest in carrying the research and publishing this manuscript.

\section{REFERENCES}

Alvares CA, Sentelhas PC \& Stape JL (2017) Modeling monthly meteorological and agronomic frost days, based on minimum air temperature, in Center-Southern Brazil. Theoretical Applied Climatology, 34:177-191.

Boscardin J (2016) Artrópodos associados à cultura da nogueirapecã [Carya illinoinensis (Wangenh.) K. Koch] no Rio Grande do Sul. Tese de Doutorado. Universidade Federal de Santa Maria, Santa Maria. 197p.

Boscardin J, Costa EC, Pedron L, Machado DN \& Silva JM (2016) Primer registro de chinches (Hemiptera: Coreidae y Pentatomidae) atacando frutos de nogal pecanero en Brasil. Revista Colombiana de Entomología, 46:12-15. 
Boscardin J \& Costa EC (2018) A nogueira-pecã no Brasil: uma revisão entomológica. Ciência Florestal, 28:456-468.

Carrano-Moreira AF (2014) Manejo integrado de pragas florestais: Fundamentos Ecológicos Conceitos e táticas de controle. Rio de Janeiro, Technical Books. 342p.

Ciesla W (2011) Bark and ambrosia beetles. In: Ciesla W (Ed.) Forest Entomology: a global perspective. Chichester, WileyBlackwell. p.173- 202

Dorval A, Peres Filho O \& Marques EN (2004) Levantamento de Scolytidae (Coleoptera) em plantações de Eucalyptus spp. em Cuiabá, Estado de Mato Grosso. Ciência Florestal 14:47-58.

Divinut (2016) Saúde, sabor e requinte. Available at: <https:// www.divinut.com.br/blog/294/saude-sabor-e-requinte-e-divinut $>$. Accessed on August 20 2019.

Flechtmann CAH, Couto HTZ, Gaspareto CL \& Bert Filho E (1995) Manual de pragas em florestas Scolytidae em reflorestamento com pinheiros tropicais $4^{\mathrm{a}}$ ed. Piracicaba, IPEF. 201p.

Flechtmann CAH (2000) Scolytidae in pine plantations overviews and situation in Brazil. Série Técnica IPEF, 13:49-56.

Gullan PJ \& Cranston PS (2014) The insects: An Outline of Entomology. In: Gullan PJ \& Cranston PS (Eds.) GroundDwelling Insects. Chichester, Wiley Blackwell. p.247- 270.

IBGE - Instituto Brasileiro de Geografia e Estatística (2016) Produção Agrícola Municipal: culturas temporárias e permanentes 2016. Available at: <https://biblioteca.ibge.gov.br/visualizacao/ periodicos/66/pam_2016_v43_br.pdf $\geq$. Accessed on: August $20^{\text {th }}$, 2019 .
Machado LM, Costa EC, Magistrali IC, Boscardin J, Machado DN \& Garlet J (2014) Escolitíneos associados a uma população de acácia-negra (Acacia mearnsii De Wild). Biotemas, 27:57-63.

McWilliams J (2013) The pecan: A history of America's native nut. Austin, University of Texas Press. 192p.

Raffa KF, Grégoire JC \& Staffan BL (2015) Natural History and Ecology of Bark Beetles. In: Vega FE \& Hofstetter RW (Eds.) Bark Beetles - Biology and Ecology of Native and Invasive Species. Flagstaff, Academic Press. p. 01-40.

Rassati D, Faccoli M, Haack RA, Rabaglia RJ, Toffolo EP, Battisti A \& Lorenzo Marini L (2016) Bark and Ambrosia Beetles Show Different Invasion Patterns in the USA. PLoS ONE, 11:e0158519.

Solomon JD \& Payne EJA (1986) A Guide to the Insect Borers, Pruners, and Girdlers of Pecan and Hickory. New Orleans, USDA. 31p. (General Technical Report, SO-64).

Wood SL (1982) The bark and ambrosia beetles of North and Central America (Coleoptera: Scolytidae), a taxonomic monograph. Provo, Brigham Young University. 1359p.

Wollmann J, Garcia MS, Flechtmann CAH, Finkenauer E \& Garcia FRM (2017) Estrutura da assembleia de Scolytinae (Coleoptera: Curculionidae) em áreas florestadas com Eucalyptus spp. no sul do Rio Grande do Sul. Ciência Florestal, 27:1167-1177. 